\title{
Eplerenon w codziennej praktyce - aktualne miejsce w terapii i perspektywy stosowania w Polsce. Stanowisko ekspertów wsparte przez Sekcję Farmakoterapii Sercowo-Naczyniowej Polskiego Towarzystwa Kardiologicznego
}

\author{
Eplerenone in everyday practice - current place in therapy and prospects \\ of application in Poland. Expert Group Consensus endorsed \\ by the Polish Cardiac Society Working Group on Cardiovascular Pharmacotherapy
}

Filip M. Szymański ${ }^{1}$, Krzysztof J. Filipiak ${ }^{1}$, Artur Mamcarz ${ }^{2}$, Beata Wożakowska-Kapłon ${ }^{3,4}$, Jarosław Drożdż ${ }^{5}$, Andrzej Tykarski ${ }^{6}$

${ }^{1}$ I Katedra i Klinika Kardiologii Warszawskiego Uniwersytetu Medycznego

${ }^{2}$ III Klinika Chorób Wewnętrznych i Kardiologii Warszawskiego Uniwersytetu Medycznego

${ }^{3}$ I Klinika Kardiologii i Elektroterapii Świętokrzyskiego Centrum Kardiologii w Kielcach

${ }^{4}$ Wydział Nauk o Zdrowiu Uniwersytetu Jana Kochanowskiego w Kielcach

${ }^{5}$ Klinika Kardiologii Uniwersytetu Medycznego w Łodzi

${ }^{6}$ Klinika Nadciśnienia Tętniczego, Chorób Naczyń i Chorób Wewnętrznych Uniwersytetu Medycznego w Poznaniu

\section{Streszczenie}

Eplerenon i spironolakton stanowią dwa najczęściej stosowane leki z grupy antagonistów aldosteronu - leków zajmujących istotną pozycję w schematach leczenia przede wszystkim niewydolności serca i nadciśnienia tętniczego, ale także innych schorzeń, takich jak pierwotny hiperaldosteronizm czy obrzęki obwodowe. Poniższe stanowisko ekspertów w dziedzinie kardiologii oraz hipertensjologii stanowi podsumowanie aktualnej wiedzy na temat antagonistów aldosteronu oraz próbę sprecyzowania wskazań do ich stosowania oraz określenia pozycji obu leków w obowiązujących obecnie wytycznych towarzystw naukowych.

Słowa kluczowe: eplerenon, niewydolność serca, nadciśnienie tętnicze

(Folia Cardiologica 2015; 10, 4: 288-293)

Adres do korespondencji: dr hab. n. med. Filip M. Szymański, I Katedra i Klinika Kardiologii, Warszawski Uniwersytet Medyczny, ul. Banacha 1a, 02-097 Warszawa, tel. +48 2259919 58, faks: +48 22599 19 57, e-mail: filip.szymanski@wum.edu.pl 


\section{"Starzy i nowi" antagoniści aldosteronu - porównanie właściwości farmakologicznych i klinicznych}

Antagoniści aldosteronu są jedną z grup leków hamujących układ renina-angiotensyna-aldosteron (RAA). Zarówno eplerenon, jak i starszy przedstawiciel antagonistów aldosteronu - spironolakton to obecnie dwa najczęściej stosowane leki z tej grupy. Są antagonistami receptora mineralokortykoidowego - jednego z ostatnich ogniw układu RAA. Aldosteron najsilniej oddziałuje w kanalikach nerkowych, gdzie - łącząc się z receptorami mineralokortykoidowymi w kanalikach dalszych i cewkach zbiorczych nefronu - aktywuje pompę $\mathrm{Na}^{+} / \mathrm{K}^{+}$i powoduje reabsorpcję sodu i wody oraz zwiększenie wydalania potasu i jonów wodorowych, co z kolei wpływa na wzrost ciśnienia tętniczego [1]. Ponadto aldosteron wywołuje wiele innych działań nieograniczających się wyłącznie do układu sercowo-naczyniowego. Moduluje ekspresję genów, powodujących remodeling mięśnia sercowego i naczyń krwionośnych oraz stymulujących proliferację mięśniówki gładkiej, wywiera bezpośredni wpływ naczynioskurczowy, a w mieszanych mechanizmach stymuluje reakcję zapalną, zwiększa stres oksydacyjny, zmniejsza biodostępność tlenku azotu i reaktywność naczyń krwionośnych oraz powoduje odkładanie kolagenu i stymulację tworzenia tkanki łącznej [2-4]. Cechuje go także częściowa zdolność do stymulacji receptorów dla angiotensyny [4]. Nie dziwi zatem, że zablokowanie działania aldosteronu łączy się nie tylko z obniżeniem wartości ciśnienia tętniczego, ale wywołuje również wiele innych, korzystnych działań w układzie sercowo-naczyniowym.

Początkowo antagonistów aldosteronu stosowano głównie jako diuretyki oszczędzające potas, co powodowało, że wskazania do ich stosowania były ograniczone. Pierwszym wprowadzonym na rynek lekiem z tej grupy był spironolakton, który zsyntetyzowano w latach 50 . ubiegłego wieku. Jego budowa powodowała znaczne powinowactwo nie tylko do receptora mineralokortykoidowego, ale również androgenowego i progesteronowego, co wiązało się z wysoką częstością występowania działań niepożądanych, takich jak ginekomastia, zaburzenia libido, spadek potencji u mężczyzn i zaburzenia cyklu miesiączkowego u kobiet. Wprowadzony później eplerenon nie wykazywał już tego typu nasilonego działania. Porównanie właściwości eplerenonu i spironolaktonu przedstawiono w tabeli 1 [5].

Silniejsze powinowactwo spironolaktonu do receptorów innych niż mineralokortykoidowe przekłada się na zwiększone ryzyko działań niepożądanych. W najważniejszych badaniach dotyczących obu substancji częstość występowania najczęstszych działań niepożądanych związanych z przyjmowaniem antagonistów aldosteronu, tj. ginekomastii i mastodynii, była porównywalna z cechującą placebo po zastosowaniu eplerenonu, natomiast u pacjentów leczonych spironolaktonem - 20-krotnie większa (10\% pacjentów) [6]. Podobnie inne działania niepożądane, takie jak zaburzenia libido, spadek potencji w grupie mężczyzn i zaburzenia cyklu miesiączkowego u kobiet, częściej obserwuje się po podaniu spironolaktonu.

Tabela 1. Porównanie właściwości farmakologicznych i klinicznych eplerenonu i spironolaktonu (zmodyfikowano na podstawie [5])

$\begin{array}{lcc}\text { Cecha } & \text { Spironolakton } & \text { Eplerenon } \\ \text { Właściwości farmakokinetyczne } & & \\ \text { Wiązanie z białkami osocza } & 90 \% & \sim 50 \% \\ \text { Indukcja enzymów mikrosomalnych (układu cytochromu P450) } & + & - \\ \text { Hamowanie glikoproteiny P } & + & - \\ \text { Obecność aktywnych metabolitów } & + & 4-6 \mathrm{~h} \\ \text { Okres półtrwania } & 14-16,5 \text { h w przypadku } \\ & \text { aktywnych metabolitów } & \\ \text { Działania niepożądane } & + \\ \text { Ginekomastia, impotencja, zaburzenia miesiączkowania } & + \\ \text { Hiperkaliemia } & + \\ \text { Wzrost stężenia kreatyniny } & ++ \\ \text { Kancerogenność w modelach zwierzęcych } & + \\ \text { Agranulocytoza } & + \\ \text { Interakcje z lekami i pożywieniem } & + \\ \text { Ryzyko interakcji lekowych wynikających z dużego wiązania z białkami osocza, } & + \\ \text { indukcją cytochromu P450 i hamowaniem glikoproteiny P } & + \\ \text { Interakcje z pokarmem } & & - \\ \end{array}$




\section{Antagoniści aldosteronu w badaniach klinicznych}

Antagoniści aldosteronu to grupa leków o udowodnionych, korzystnych właściwościach klinicznych. Wykazują one skuteczność hipotensyjną, ale przede wszystkim korzystnie wpływają na rokowanie pacjentów z niewydolnością serca. Podstawą do ich szerokiego zastosowania klinicznego w tym drugim wskazaniu były przede wszystkim wyniki trzech największych badań klinicznych, tj.: RALES (Randomized Aldactone Evaluation Study), EPHESUS (Eplerenone Post-Acute Myocardial Infarction Heart Failure Efficacy and Survival Study) i EMPHASIS-HF (Eplerenone in Mild Patients Hospitalization and Survival Study in Heart Failure) [7].

Pierwsze z badań - RALES - dotyczyło pacjentów z rozpoznaną niewydolnością serca wykazujących objawy w III lub IV klasie według New York Heart Association (NYHA). Pacjentów tych poddano randomizacji do przyjmowania placebo bądź spironolaktonu (w dawce $\leq 50 \mathrm{mg} / \mathrm{d}$.) dodanych do typowego leczenia niewydolności serca. Po 24 miesiącach stosowania spironolaktonu zaobserwowano istotne różnice w stosunku do śmiertelności całkowitej, odnotowując jej zmniejszenie o 30\% (0,70; 95-proc. przedział ufności [Cl, confidence interval] 0,60-0,82; $p<0,001$ ). Także ryzyko wystąpienia innych punktów końcowych, takich jak zgon sercowo-naczyniowy (ryzyko względne [RR, relative risk]
0,69; 95\% Cl 0,58-0,82; $\mathrm{p}<0,001$ ) oraz zgon spowodowany zaostrzeniem niewydolności serca, uległo redukcji [7].

Kolejne badanie, o akronimie EPHESUS, objęło pacjentów po świeżym zawale serca, z frakcją wyrzutową lewej komory nie większą niż 40\%, u których występowały kliniczne objawy niewydolności serca, oraz chorych na cukrzycę spełniających dwa pierwsze z wymienionych kryteriów, bez względu na objawy niewydolności serca; także w tym badaniu wszyscy pacjenci byli leczeni w sposób typowy w niewydolności serca [8]. Stosowano u nich eplerenon - początkowo w dawce dobowej $25 \mathrm{mg}$, zwiększanej do $50 \mathrm{mg} /$ dobę pod kontrolą stężenia potasu w surowicy. Zaobserwowany wpływ leku na punkty końcowe przedstawiono w tabeli 2.

Z kolei badanie EMPHASIS-HF dotyczyło pacjentów w wieku powyżej 55 lat, u których frakcja wyrzutowa lewej komory nie przekraczała 30\% (lub 35\% w przypadku stwierdzenia w zapisie elektrokardiograficznym czasu trwania zespołu QRS > $130 \mathrm{~ms}$ ), bez świeżego zawału serca, których w przypadku braku przeciwwskazań leczono inhibitorem konwertazy angiotensyny i/lub sartanem oraz $\beta$-adrenolitykiem [9]. Również w tym badaniu pacjenci byli leczeni eplerenonem w początkowej dawce dobowej $25 \mathrm{mg}$, zwiększanej do $50 \mathrm{mg} /$ dobę pod kontrolą stężenia potasu w surowicy i funkcji nerek. Stwierdzony w tym przypadku wpływ leku na punkty końcowe przedstawiono w tabeli 3.

Tabela 2. Wpływ eplerenonu na punkty końcowe w badaniu EPHESUS (na podstawie [8])

$\begin{array}{lcc}\text { Punkt końcowy } & \begin{array}{c}\text { Ryzyko względne (RR, relative risk), } \\ 95-\text { proc. cl }\end{array} & \begin{array}{c}\text { Względna redukcja ryzyka } \\ \text { w porównaniu z placebo }\end{array} \\ \text { Śmiertelność całkowita } & 0,86(0,77-0,96) & \downarrow 14 \% \\ \text { Zgon lub hospitalizacja z przyczyn sercowo-naczyniowych } & 0,89(0,82-0,96) & \downarrow 11 \% \\ \text { Hospitalizacja z przyczyn sercowo-naczyniowych } & 0,93(0,84-1,03) & N S \\ \text { Zgon sercowo-naczyniowy } & 0,84(0,74-0,95) & \downarrow 16 \% \\ \text { Działania niepożądane } & 0,99(0,97-1,02) & \text { NS } \\ \text { Nagły zgon } & 0,80(0,66-0,98) & \downarrow 20 \%\end{array}$

Tabela 3. Wpływ eplerenonu na punkty końcowe w badaniu EMPHASIS-HF (na podstawie [9])

\begin{tabular}{lcc}
\hline Punkt końcowy & $\begin{array}{c}\text { Ryzyko względne (RR, relative risk), } \\
95-\text { proc. Cl }\end{array}$ & $\begin{array}{c}\text { Względna redukcja ryzyka } \\
\text { w porównaniu z placebo }\end{array}$ \\
$\begin{array}{l}\text { Zgon sercowo-naczyniowy lub hospitalizacja } \\
\text { z powodu niewydolności serca }\end{array}$ & $0,70(0,61-0,81)$ & $\downarrow 30 \%$ \\
$\begin{array}{l}\text { Śmiertelność całkowita lub hospitalizacja } \\
\text { z powodu niewydolności serca }\end{array}$ & $0,72(0,63-0,83)$ & $\downarrow 28 \%$ \\
Śmiertelność całkowita & $0,81(0,67-0,97)$ & $\downarrow 19 \%$ \\
Zgon sercowo-naczyniowy & $0,80(0,65-0,98)$ & $\downarrow 20 \%$ \\
Hospitalizacja z dowolnej przyczyny & $0,84(0,75-0,93)$ & $\downarrow 16 \%$
\end{tabular}

$\mathrm{Cl}$ (confidence interval) - przedział ufności; NS - nieistotna statystycznie 
Wyniki trzech powyższych badań, a także ich późniejszych analiz oraz kolejnych badań, takich jak na przykład REMINDER (A Double-Blind, Randomized, Placebo-Controlled Trial Evaluating The Safety And Efficacy Of Early Treatment With Eplerenone In Patients With Acute Myocardial Infarction) [10], stały się podstawą do umieszczenia antagonistów aldosteronu w schematach leczenia pacjentów zarówno z niewydolnością serca, jak i z nadciśnieniem tętniczym.

\section{Miejsce antagonistów aldosteronu w wytycznych towarzystw naukowych}

Opisując miejsce eplerenonu w wytycznych towarzystw naukowych, należy oddzielnie wyróżnić jego pozycję w kilku dokumentach oraz w kilku odrębnych wskazaniach. Wskazania do stosowania antagonistów aldosteronu obejmuja niewydolność serca (oraz pozawałowe uszkodzenie lewej komory serca), nadciśnienie tętnicze i hiperaldosteronizm.

\section{Wytyczne dotyczące leczenia} niewydolności serca

W wytycznych Europejskiego Towarzystwa Kardiologicznego (ESC, European Society of Cardiology) dotyczących rozpoznawania i leczenia niewydolności serca pozycja antagonistów aldosteronu została jasno określona [11]. W grupie pacjentów z niewydolnością serca cele jej leczenia polegają przede wszystkim na ograniczeniu objawów choroby oraz poprawie rokowania. Antagoniści aldosteronu są lekami poprawiającymi rokowanie chorych, co wyraża się w postaci redukcji ryzyka zarówno zgonu, jak i liczby hospitalizacji.

W wytycznych ESC podano, że „Stosowanie antagonisty aldosteronu jest zalecane u wszystkich pacjentów z utrzymującymi się objawami (nasilenie w skali wg NYHA II-IV) oraz frakcją wyrzutową mniejszą lub równą 35\%, mimo stosowania $\beta$-adrenolityku oraz inhibitora konwertazy angiotensyny (lub w razie jego nietolerancji - sartanu), w celu redukcji ryzyka hospitalizacji z powodu niewydolności serca oraz przedwczesnego zgonu" [11]. Zapis ten oraz określenie wskazań do stosowania leków z tej grypy są podyktowane wynikami opisywanych wyżej badań RALES, EMPHASIS-HF i EPHESUS i łączą się z obserwowaną, istotną poprawą rokowania w tej grupie chorych. W wytycznych nie podano, co prawda, który z dostępnych w Polsce antagonistów aldosteronu (eplerenon czy spironolakton) jest lekiem preferowanym, niemniej jednak uznano, że w zakresie poprawy rokowania leki te cechują się podobną skutecznością, przy czym stosowanie eplerenonu łączy się z niższym ryzykiem wystąpienia działań niepożądanych niż obserwowane u osób stosujących spironolakton [11].

Przeciwwskazania do stosowania eplerenonu, które wyszczególniono w wytycznych ESC, obejmują jednoczesne podawanie silnych inhibitorów CYP3A4, takich jak na przy- kład ketokonazol, nefazodon, klarytromycyna, ritonawir, nelfinawir. Polecono również zachowanie ostrożności w przypadku jednoczesnego podawania antagonistów aldosteronu z suplementami potasu, diuretykami oszczędzającymi potas, inhibitorami konwertazy angiotensyny, sartanami, inhibitorami reniny, niesteroidowymi lekami przeciwzapalnymi, trimetoprimem, sulfametoksazolem oraz produktami „niskosodowymi”, w których sód zastępuje się potasem.

\section{Wytyczne dotyczące leczenia nadciśnienia tętniczego}

W Polsce obowiązują obecnie dwa dokumenty o statusie wytycznych dotyczących diagnozowania i leczenia nadciśnienia tętniczego. Pierwszy z nich został przygotowany przez ESC w 2013 roku, drugi, bardziej aktualny, to opracowane w 2015 roku zalecenia Polskiego Towarzystwa Nadciśnienia Tętniczego (PTNT) $[12,13]$.

W wytycznych ESC z 2013 roku [12] eplerenon oraz spironolakton opisano $\mathrm{w}$ paragrafie odnoszącym się do diuretyków i ich zastosowania w leczeniu nadciśnienia tętniczego. Rzeczywiście, antagoniści aldosteronu są lekami wykazującymi działanie moczopędne i na początku swojej historii klasyfikowano je jako diuretyki oszczędzające potas. W wytycznych ESC podkreślono, że zarówno spironolakton, jak i eplerenon wykazuje korzystne działanie - zwłaszcza u pacjentów z niewydolnością serca. Podkreślono również, że antagoniści aldosteronu są lekami, które mogą być stosowane w 3. lub 4. rzucie leczenia pierwotnego nadciśnienia tętniczego oraz korzystnie oddziałującymi w leczeniu pierwotnego hiperaldosteronizmu. W tych samych wytycznych odrębny paragraf poświęcono leczeniu opornego nadciśnienia tętniczego. Zwrócono w nim uwagę, że antagoniści aldosteronu mogą wykazywać korzystne działanie wyrażone istotnym obniżeniem ciśnienia tętniczego i poprawą kontroli choroby. Potencjalny mechanizm działania tych leków u pacjentów z opornym nadciśnieniem tętniczym może wynikać z faktu, że u większości wspomnianych chorych występują stosunkowo wysokie stężenia aldosteronu, w związku z czym zastosowanie antagonistów tego hormonu może być leczeniem szczególnie skutecznym. Dodatkowym atutem związanym ze stosowaniem antagonistów aldosteronu w tej grupie chorych może być hamowanie efektu ucieczki aldosteronu (ang. aldosterone rebound effect) oraz potencjalne przyczynowe leczenie rzadko rozpoznawanego pierwotnego hiperaldosteronizmu.

Drugim dokumentem systematyzującym zasady postępowania w nadciśnieniu tętniczym, obowiązującym w Polsce, są wytyczne PTNT. Jest to „najmłodszy” z omawianych dokumentów, bo opublikowany w połowie 2015 roku [13]. Antagonistów aldosteronu przypisano w nim do „innych grup leków pomocnych w terapii nadciśnienia tętniczego”. W wytycznych PTNT zbiorowo w odniesieniu do „innych grup leków (...)" podano, że ze względu na brak dostępnych badań prospektywnych służących ocenie wpływu tych 
leków na śmiertelność i ryzyko sercowo-naczyniowe w terapii hipotensyjnej obecnie nie zaleca się ich stosowania w 1. i 2. wyborze w leczeniu nadciśnienia tętniczego. Nie wyklucza to jednak ich wykorzystania w terapii skojarzonej w przypadku indywidualnych wskazań oraz w nadciśnieniu tętniczym opornym, na ogół jako leków 4. i 5. rzutu. Jednocześnie dodano następujący zapis: „Podobnie jak w przypadku podstawowych grup leków, przesłanki patofizjologiczne, różnice farmakokinetyczne i różnice w nasileniu występowania działań niepożądanych sugerują większą przydatność kliniczną określonych preparatów w obrębie innych grup leków hipotensyjnych. Szczególnie dotyczy to preferencji dla (...) eplerenonu względem spironolaktonu (mniejsze działania niepożądane) wśród antagonistów aldosteronu" [13].

Wskazuje to, że według obecnych zaleceń PTNT eplerenon - jako nowszy, selektywny antagonista receptora mineralokortykoidowego, charakteryzujący się słabszym działaniem antyandrogenowym i agonistycznym na receptor progesteronowy, a więc mniejszą częstością występowania działań niepożądanych - jest lekiem preferowanym względem spironolaktonu. W wytycznych porównano także siłę działania hipotensyjnego eplerenonu w stosunku do spironolaktonu, określoną na $60 \%$, oraz zalecono stosowanie eplerenonu w terapii hipotensyjnej 2 razy/dobę w dawce po 25 mg. Pierwszą część tej informacji można traktować jako zwrócenie uwagi na fakt, że tożsame wagowo dawki spironolaktonu i eplerononu nie są ekwihipotensyjne. W przypadkach, w których chciałoby się zastosować na przykład 25 mg sprionolaktonu, warto zastosować silniejszy lek - 50 mg eplerenonu. Uwaga o podawaniu 2 razy/dobę wiąże się z rozważaniami na temat stosowaniu tego leku w nadciśnieniu tętniczym opornym. We zarejestrowanych wskazaniach eplerenon powinien być podawany raz na dobę.

W wytycznych PTNT zwrócono również uwagę na jeszcze jeden istotny prawnie i klinicznie aspekt. Obecnie eplerenon w „Charakterystyce Produktu Leczniczego w Polsce” nie ma wskazania do leczenia niepowikłanego nadciśnienia tętniczego, mimo to PTNT zaleca jego stosowanie i preferowanie wobec spironolaktonu.

W omawianym dokumencie dodano ponadto następujący zapis dotyczący eplerenonu: „W terapii hipotensyjnej u pacjentów z ryzykiem wystąpienia migotania przedsionków de novo lub nawrotu migotania można rozważyć zastosowanie inhibitora konwertazy angiotensyny lub sartanu, a przy współistnieniu niewydolności serca - eplerenon" [13]. Jest to unikatowe stwierdzenie w skali innych wytycznych i wskazań do stosowania tego leku, a wynika bezpośrednio z obserwacji post hoc chorych objętych randomizacją w badaniu EMPHASIS-HF. Wynika z niej, że prewencyjne stosowanie eplerenonu u chorych z uszkodzoną lewą komorą serca obniża ryzyko napadowego migotania przedsionków.
Wytyczne dotyczące leczenia hiperaldosteronizmu

Hiperaldosteronizm jest jedną z częstych potencjalnych przyczyn wtórnego nadciśnienia tętniczego oraz jego trudnej do leczenia postaci opornej. Dlatego, zarówno w wytycznych ESC jak również PTNT osobne ustępy poświęcono leczeniu tego schorzenia [2, 3]. Niemniej jednak istnieja osobne wytyczne sygnowane przez Towarzystwo Endokrynologiczne (Endocrine Society), które skupiają się wyłącznie na hiperaldosteronizmie pierwotnym, jest to jednak dokument pochodzący z 2008 roku, którego aktualizacja spodziewana jest w najbliższym czasie [14].

W wytycznych ESC/ESH (European Society of Hypertension - Europejskiego Towarzystwa Nadciśnienia Tętniczego) sprecyzowano, że w przypadku pierwotnego aldosteronizmu spowodowanego gruczolakiem produkującym aldosteron lub jednostronnym przerostem nadnerczy leczeniem z wyboru jest laparoskopowa adrenalektomia, natomiast w przypadku postaci zajmującej dwa nadnercza wskazane jest leczenie spironolaktonem lub eplerenonem. W wytycznych nie wskazano jednej preferowanej substancji spośród tych dwóch leków, zwrócono natomiast uwage na to, że ryzyko działań niepożądanych zwiększa się w przypadku wyboru spironolaktonu oraz że wybór eplerenonu powoduje konieczność odmiennego dawkowania ze względu na inną farmakokinetykę leku [12]. Opisane zalecenia niemal w tym samym brzmieniu utrzymano w wytycznych PTNT, dodając jednak informację o braku rejestracji eplerenonu w leczeniu pierwotnego hiperaldosteronizmu na terenie Unii Europejskiej, mimo udowodnionej skuteczności tego leku. Wybierając antagonistę aldosteronu do terapii hiperaldosteronizmu należy jednak kierować się również profilem działań niepożądanych obu substancji [13]. W wytycznych Towarzystwa Endokrynologicznego z 2008 roku również zalecono stosowanie antagonistów aldosteronu u pacjentów z obustronną patologią nadnerczy [14].

\section{Podsumowanie}

Zarówno selektywny eplerenon, jak i nieselektywny spironolakton to przedstawiciele grupy antagonistów aldosteronu najczęściej stosowani w Polsce. Oba leki cechuje udowodniona w badaniach klinicznych skuteczność, aczkolwiek eplerenon przebadano w szerszej grupie chorych. Zarówno eplerenon, jak i spironolakton ma ugruntowaną pozycje w wytycznych towarzystw naukowych. Podobny profil korzyści ze stosowania obu substancji każe zwracać większą uwagę na dodatkowe, korzystne dla pacjentów, właściwości obu leków. W tym kontekście eplerenon jest lekiem znacznie przewyższającym spironolakton pod względem ryzyka wystąpienia działań niepożądanych.

W Polsce, w 2014 roku, przepisano około 12 razy więcej recept na spironolakton niż na eplerenon. Pojawienie się generycznych postaci eplerenonu poprawia jednak 
kosztowo-efektywne wskaźniki stosowania tych leków i sprzyjać powinno w najbliższych latach zmianie tych niekorzystnych proporcji w częstości zastosowania eplerenonu w porównaniu ze spironoloaktonem oraz znacznie szerszemu zastosowaniu tego pierwszego.

\section{Konflikt interesów}

Autorzy zgłaszają honoraria za wykłady, udział w grupach doradczych: Adamed, Pfeizer, Polfa Pabianice, Polpharma SA, Valeant, Zentiva.

\begin{abstract}
Eplerenone and spironolactone are the two most commonly used aldosterone antagonists - drugs having an important position in the treatment regiments, most of all, of heart failure and hypertension, but also other diseases, such as primary aldosteronism or peripheral edema. The following review article written by experts in the field of cardiology and hypertension is a summary of current knowledge on aldosterone antagonists and an attempt to clarify the indications for their use and determine the position of the two drugs in the current guidelines of scientific societies.
\end{abstract}

Key words: eplerenone, heart failure, hypertension

(Folia Cardiologica 2015; 10, 4: 288-293)

\section{Piśmiennictwo}

1. Rocha R., Funder J.W. The pathophysiology of aldosterone in the cardiovascular system. Ann. NY Acad. Sci. 2002; 970: 89-100.

2. Lombès M., Alfaidy N., Eugene E. i wsp. Prerequisite for cardiac aldosterone action. Mineralocorticoid receptor and 11 beta-hydroxysteroid dehydrogenase in the human heart. Circulation 1995; 92: 175-182.

3. Brown N.J. Eplerenone: cardiovascular protection. Circulation 2003; 107: 2512-2528.

4. Maron B,, Leopold J. Aldosterone receptor antagonists: effective, but often forgotten. Circulation 2010; 121: 934-939.

5. Kapłon-Cieślicka A,, Filipiak K,J. Eplerenon - co wiadomo o tym leku na początku 2009 roku? Choroby Serca i Naczyń 2009; 6: 26-36.

6. Garthwaite S.M., McMahon E.G. The evolution of aldosterone antagonists. Mol. Cell. Endocrinol. 2004; 217: 27-31.

7. Pitt B., Zannad F., Remme W.J. i wsp. The effect of spironolactone on morbidity and mortality in patients with severe heart failure. Randomized Aldactone Evaluation Study Investigators. N. Engl. J. Med. 1999; 341: 709-717.

8. Pitt B., Remme W., Zannad F. i wsp. Eplerenone, a selective aldosterone blocker, in patients with left ventricular dysfunction after myocardial infarction. N. Engl. J. Med. 2003; 348: 1309-1321.

9. Zannad F., McMurray J.J., Krum H. i wsp.; EMPHASIS-HF Study Group. Eplerenone in patients with systolic heart failure and mild symptoms. N. Engl. J. Med. 2011; 364: 11-21.
10. Montalescot G., Zannad F., Lopez de Sa E. i wsp. Early administration of eplerenone in patients with acute myocardial infarction without heart failure: results of the randomized, double-blind, placebo-controlled REMINDER Trial. American College of Cardiology 2013 Scientific Sessions. 10 marca 2013, San Francisco, California.

11. McMurray J.J., Adamopoulos S., Anker S.D. i wsp.; ESC Committee for Practice Guidelines. ESC Guidelines for the diagnosis and treatment of acute and chronic heart failure 2012: The Task Force for the Diagnosis and Treatment of Acute and Chronic Heart Failure 2012 of the European Society of Cardiology. Developed in collaboration with the Heart Failure Association (HFA) of the ESC. Eur. Heart J. 2012; 33: 1787-1847.

12. Mancia G., Fagard R., Narkiewicz K. i wsp. 2013 ESH/ESC guidelines for the management of arterial hypertension: the Task Force for the Management of Arterial Hypertension of the European Society of Hypertension (ESH) and of the European Society of Cardiology (ESC). Eur. Heart J. 2013; 34: 2159-2219.

13. Tykarski A., Narkiewicz K., Gaciong Z. i wsp. Zasady postępowania w nadciśnieniu tętniczym - 2015 rok. Wytyczne Polskiego Towarzystwa Nadciśnienia Tętniczego. Arterial Hypertens. 2015; 19: 53-58.

14. Funder J.W., Carey R.M., Fardella C. i wsp. Endocrine Society. Case detection, diagnosis, and treatment of patients with primary aldosteronism: an endocrine society clinical practice guideline. J. Clin. Endocrinol. Metab. 2008; 93: 3266-3281. 